\title{
TFG/ALK Extra Long Form Fusion Protein
}

National Cancer Institute

\section{Source}

National Cancer Institute. TFG/ALK Extra Long Form Fusion Protein. NCI Thesaurus.

Code C101082.

A fusion protein (803 aa, 89 kDa) encoded by the TFG/ALK extra long form fusion gene.

This protein is comprised of the $\mathrm{N}$-terminal half of protein TFG, including the coiled-coil

oligomerization domain, fused to the cytoplasmic domain of the ALK tyrosine kinase receptor protein. 